\title{
Appropriate level of gilt fatness and muscularity during insemination can improve the efficiency of piglet production
}

\author{
Damian Knecht, Sebastian Środoń, Anna Jankowska-Mąkosa, Kamil Duziński ${ }^{1}$
}

Institute of Animal Breeding, Wroclaw University of Environmental and Life Sciences, 51-630 Wroclaw, Poland.

\begin{abstract}
The aim of this study was to determine the degree of fatness and muscularity of gilts with different genotypes on the basis of intravital measurements using an Aloka SSD-500 ultrasound scanner and defining the influence of these parameters on selected indicators of reproductive performance. Research was performed on 462 gilts maintained under the same production conditions. Gilts were divided into 3 groups according to genotype: 154 Landrace gilts (L), 154 Large White (LW), 154 Landrace $\times$ Large White $-[\mathrm{L} \times$ LW] . Four selected reproductive indicators were analyzed: the number of piglets born alive $(\mathrm{n})$, average piglet birth weight $(\mathrm{kg})$, number of piglets weaned at 28 days (n) and the average weaned piglet weight $(\mathrm{kg})$. Our results clearly show that an appropriate level of gilt fatness during insemination can contribute to significant improvements in the efficiency of piglet production. In order to increase the number of piglets born alive, the number of piglets at weaning and the masses in these periods, it is recommended insemination of $\mathrm{L}, \mathrm{LW}$ and $[\mathrm{L} \times \mathrm{LW}]$ gilts when their backfat thickness behind the last rib $3 \mathrm{~cm}$ from the midline of the spine exceeds $25 \mathrm{~mm}$. In the case of backfat thickness measured $8 \mathrm{~cm}$ from the midline of the spine, to improve the production efficiency of these gilts it is recommended to proceed to insemination, when the value of this trait exceeds $20 \mathrm{~mm}$. In addition, insemination of gilts with the genotype $[\mathrm{L} \times \mathrm{LW}]$ should occur when the amount of LD muscle exceeds $60 \mathrm{~mm}$, the width of the muscle is greater than $135 \mathrm{~mm}$, and its surface is greater than $70 \mathrm{~cm}^{2}$.
\end{abstract}

Keywords: Aloka SSD-500, birth, body composition, female pigs, reproductive performance, weaning.

\section{Introduction}

The reorientation of pork consumer preferences caused by the global trend for a healthy lifestyle directly changed the characteristics of pig meat. Pork has to be characterised by a high content of lean meat with a low proportion of fat (Resurreccion, 2004). Such situation forced a permanent change in the nationals breeding programs. It began to focus primarily on increasing pigs content of lean muscle. During an analysis of changes in the slaughter traits of gilts, there is a significant improvement in the value of these traits, particularly in terms of meat content in the carcass, which in Landrace and Large White gilts has already increased to around 59\% (Szulc et al., 2013; Blicharski et al., 2014).

Numerous studies (Zhang et al., 2000; Holm et al., 2004; Imboonta et al., 2007; Patterson et al., 2010; Kim et al., 2013; Szulc et al., 2013) reported that important relationships exist between body composition and reproduction. This was also confirmed in the research of Tummaruk et al. (2001), Čechova and Tvrdoň (2006), and Mijatović et al. (2009). Gilts reach puberty with different body composition, however puberty is initiated by metabolic signals, among which special significance for growth and differentiation of cells plays leptin and insulin-like growth factor-I (IGFI; Bidanel et al., 1996; Barb et al., 1997; Roongsitthichai and Tummaruk, 2014). Some authors have emphasized that the traits associated with reproduction should be taken into account in the development of breeding strategies aimed at improving the fattening and slaughter traits (Kuehn et al., 2009; McPherson et al., 2014). Many authors have confirmed the occurrence of the negative impact of selection focused only on improving the fattening and slaughter traits, which exacerbate some reproductive parameters, and evidently this process can be seen precisely in the example of gilts (Tummaruk et al., 2001; Holm et al., 2004; Imboonta et al., 2007).

It should be noted that long-term and the unilateral selection for higher lean meat content has considerably decreased the level of gilt fatness at first mating. This is mainly related to the occurrence of a negative meatiness-fatness correlation, which means that with increasing meat content, the level of fatness in gilts decreases. Tummaruk et al. (2001) clearly concluded that an increase in the muscularity and a reduction in the level of fat has an adverse effect on the reproductive performance of pigs. The research of Matysiak et al. (2010) confirmed that a higher level of fatness at the moment of the first mating/insemination can improve reproductive indicators of gilts. One way to increase the level of gilt fatness may be mating/insemination for the first time at an older age (Chen et al., 2003).

According to Quinton et al. (2006), the most important from economic point of view reproductive indicators are the number of piglets born alive, the number of piglets at weaning and the weight of piglets in the same periods. It is worth noting that these parameters of gilts reproductive performance are affected by many additional factors, of which one of the most important is the quality of boar semen (Knecht et al., 2014a, b).

Taking into account the above problems, the aim of this study was to determine the degree of fatness and muscularity of gilts with different genotypes on the basis of intravital measurements using an Aloka SSD500 ultrasound scanner. Subsequently the influence of

${ }^{1}$ Corresponding author: kamil.duzinski@upwr.edu.pl 
these parameters on selected indicators of reproductive performance was defined.

\section{Materials and Methods}

\section{Experimental location and design}

The experiment was carried out in 2014 at an industrial pig fattening farm located in Poland, in the province of Opole $\left(51.0431^{\circ} \mathrm{N}, 17.8583^{\circ} \mathrm{E}\right)$. The research population consisted of gilts during first insemination with different genotypes, which the degree of fatness and muscularity was determined by ultrasound, and then investigated whether these parameters can affect the selected indicators of reproductive performance.

Experimental animals, environmental conditions and feeding

Research was performed on 462 gilts maintained under the same production conditions. Gilts were divided into 3 groups according to genotype: 154 Landrace gilts (L), 154 Large White (LW), 154 Landrace $\times$ Large White $-[\mathrm{L} \times \mathrm{LW}]$. At the time of the insemination the average weight of gilts were $127.42 \pm$ $7.45 \mathrm{~kg}$ for $\mathrm{L}, 129.32 \pm 9.59 \mathrm{~kg}$ for $\mathrm{LW}, 128.73 \pm 8.42$ $\mathrm{kg}$ for $[\mathrm{L} \times \mathrm{LW}]$, the average age were $237.18 \pm 12.14$ days for L, $238.58 \pm 16.56$ days for $L W, 250.44 \pm 14.08$ days for $[\mathrm{L} \times \mathrm{LW}]$, and the average daily gains were $577.33 \pm 15.55 \mathrm{~g}$ for $\mathrm{L}, 582.04 \pm 19.86 \mathrm{~kg}$ for $\mathrm{LW}$, $580.18 \pm 21.38 \mathrm{~kg}$ for $[\mathrm{L} \times \mathrm{LW}](\mathrm{P}>0.05)$.

Selection of gilts was carried out around the age of two months, on the basis of gilts appearance: long body, healthy leg and at least 12 active nipples. Sows, mothers of gilts were in average $2.68 \pm 0.59$ parity. Since the selection, gilts were specially fed by the appropriate composition of vitamins, micro- and macronutrients in the feed, which enable correct, comprehensive development and their subsequent use in reproduction. The average daily gain during this period was maintained below $600 \mathrm{~g}$.

The maintenance conditions of gilts were consistent with the provisions of cross compliance concerning animal welfare. Gilts after insemination were housed for 4 weeks in individual pens with an area of $1.20 \mathrm{~m}^{2}$ equipped with a slatted floor. Gilts in the period between 4 weeks after insemination to 1 week prior to farrowing were maintained in groups (22 gilts/pen), on the floor was a partially slatted grate. Pen area per gilt was $1.64 \mathrm{~m}^{2}$, with $0.95 \mathrm{~m}^{2}$ the complete floor. A week before parturition gilts were moved to partially slatted farrowing pens with a total area of $3.5 \mathrm{~m}^{2}$. The temperature in pens for gilts in early pregnancy was $14.82^{\circ} \mathrm{C} \pm 0.93$, in the case of lactating gilts and gilts in high pregnancy it was $20.05^{\circ} \mathrm{C} \pm 1.02$. Relative humidity in the premises for gilts was $70.44 \% \pm 5.11$. The movement of air inside buildings was $0.30 \mathrm{~m} / \mathrm{s}$ for the gilts in early and late pregnancy and $0.20 \mathrm{~m} / \mathrm{s}$ for lactating sows.

Gilts were fed according to Grela and Skomial (2014), with ad libitum access to water. Dietary doses for gilts after insemination to 90 days of pregnancy contained 11.8 MJ metabolisable energy, $143.6 \mathrm{~g}$ of digestible protein, $6.4 \mathrm{~g}$ lysine, $5.3 \mathrm{~g}$ of methionine and cystine, $8.2 \mathrm{~g}$ calcium, $6.3 \mathrm{~g}$ phosphorus and $2.7 \mathrm{~g}$ of sodium. Rations for gilts over 90 days of pregnancy and lactating gilts contained $12.5 \mathrm{MJ}$ metabolisable energy, $170.2 \mathrm{~g}$ of digestible protein, $10.1 \mathrm{~g}$ lysine, $6.5 \mathrm{~g}$ of methionine and cystine, $9.9 \mathrm{~g}$ calcium, $7.2 \mathrm{~g}$ phosphorus and $3.6 \mathrm{~g}$ of sodium. After insemination until 90 days of pregnancy, each gilt received about $2.80 \mathrm{~kg}$ of feed per day, and after this period, the amount of feed was increased to $3.30 \mathrm{~kg}$. None additional feed management after insemination was used.

\section{Insemination}

Estrus was checked twice a day with the presence of mature teaser boar. Animals were located in individual pens. Estrus was diagnosed by detecting the standing reflex using the back pressure test. The detection of estrus was started from 170 day of life gilts. Gilts were inseminated in their third heat two-times: the first time after $12 \mathrm{~h}$ of the onset of estrus and the second time after 12 to $18 \mathrm{~h}$ of the first insemination.

$\mathrm{L}, \mathrm{LW}$ and $[\mathrm{L} \times \mathrm{LW}]$ gilts were inseminated by semen of five Duroc $\times$ Pietrain boars $-[D \times P]$, with a proportionate contribution to eliminating the single boar effect. The semen was collected by the manual method (King and Macpherson, 1973), using a container with a filter and only the sperm-rich fraction was used. Ejaculates were diluted, when meet the following requirements: color from gray to milky white, flavor specific (sensoric subjective evaluation), lack of foreign admixtures, more than $70 \%$ of progressive motile sperm cells (microscopic evaluation), $\mathrm{pH}$ 7.0-7.9, maximum changes to $15 \% \quad(5 \%$ primary, $10 \%$ secondary $)$. Insemination doses (irrespective of boar genotype) were similar with the concentration of sperm cells $-3.5 \times 10^{9}$ per $100 \mathrm{ml}$. Semen was diluted using a short-term BTS boar semen extender, Version 13525/0100 Antibiotic Free, Minitube International, Verona, WI, USA. Gilts were inseminated with cooled semen stored at $15^{\circ} \mathrm{C}$ for not longer than $48 \mathrm{~h}$. Safe Blue Clear Glide (Minitube) catheters were used for the standard (cervix) insemination. Before insemination, seminal doses were heated to a temperature of $30^{\circ} \mathrm{C}$. A pregnancy test was performed twice in 29 and 35 day after insemination using ultrasound - USG DRAMINSKI ${ }^{\circledR}$ SonoFarm profi.

\section{Ultrasound measurements}

Using an Aloka SSD-500 ultrasonograph equipped with a $17 \mathrm{~cm}$ UST-5044 transducer at an operation frequency of $3.5 \mathrm{MHz}$ in vivo assessment of gilts was performed at the level of their fatness and muscularity during the first insemination. The use of the device in conjunction with dedicated computer software - Designer Gene's Image Analysis, enabled the performance of linear and surface measurements as: $\mathrm{BF}_{1}$ - backfat thickness measured at the last rib, on the border of thoracic and lumbar vertebrae $-3 \mathrm{~cm}$ from the midline of the spine $(\mathrm{mm}) ; \mathrm{BF}_{2}$ - backfat thickness measured at the last rib, on the border of thoracic and 
lumbar vertebrae $-8 \mathrm{~cm}$ from the midline of the spine $(\mathrm{mm})$; BFA - cross-sectional area of fat on the surface of the LD muscle $\left(\mathrm{cm}^{2}\right)$; HLD - height of the LD muscle measured on the border of thoracic and lumbar vertebrae $-8 \mathrm{~cm}$ from the midline of the spine $(\mathrm{mm})$; WLD - width of the LD muscle (mm); LDA - crosssectional area of the LD muscle $\left(\mathrm{cm}^{2}\right)$.

The transducer was applied perpendicular to the axis of the gilt's body. At the time of the appearance on the ultrasonograph monitor of the optimal outline of Longissimus dorsi (LD) muscle and a layer of fat over the muscle the image was immediately frozen. Then, after obtaining the best quality ultrasound image the analysis proceeded to the simultaneous performance of linear and surface measurements. It should be noted that the measurement of the width of the Longissimus dorsi muscle was performed at its widest point, which has direct relevance in the performance of measurements of the area of fat over the muscle. Average values of linear and surface measurements after the initial manual determination by the person conducting the study were calculated automatically by the Designer Gene's Image Analysis software.

After completing all measurements, gilts were divided in terms of their degree of fatness and muscularity. For each measurement, taking into account the distribution of the variables in the population, mean and standard deviation, three levels of each factor were set out in such a way that in the subgroup of research within each breed there were ultimately no less than 30 and no more than 40 gilts.

\section{Reproductive performance analysis}

The next stage of the research was to assess the reproductive performance of gilts taking part in the experiment. Farrowing rates were $92.96 \%$ for L, $92.04 \%$ for $\mathrm{LW}, 92.06 \%$ for $[\mathrm{L} \times \mathrm{LW}]$ and differences between groups were not proven statistically significant $\left(\chi^{2}\right.$ test, $\left.\mathrm{P}>0.05\right)$. Four selected reproductive indicators were analyzed: the number of piglets born alive (n), average piglet birth weight $(\mathrm{kg})$, number of piglets weaned at 28 days (n) and the average weaned piglet weight (n). Differences between gilt genotypes in relation to different degrees of fatness and muscularity were examined statistically.

\section{The statistical analysis}

In order to check the reproducibility of the results, each ultrasound measurement was performed three times. The collected data were checked for the normality of the Kolmogorov-Smirnov (KS) test with Lilliefors correction. Further, the Brown-Forsythe (BF) test was employed to determine whether the distributions of the variables had the same variance. Numerical material was statistically analyzed with STATISTICA (2014), using analysis of variance (ANOVA). The significance of differences was confirmed by Tukey's test. Levels of the significance of differences were given conventionally: significant 0.01 $<\mathrm{P} \leq 0.05$ and highly significant $\mathrm{P} \leq 0.01$. The model used was as follows:

$\mathrm{x}_{\mathrm{ijk}}=\mu+\alpha_{\mathrm{i}}+\beta_{\mathrm{j}}+\varepsilon_{\mathrm{ijk} \mathrm{l}, \text { where, }}$

$\mathrm{x}_{\mathrm{ijk}}$ - value of the dependent variable,

$\mu$ - general average,

$\alpha_{i}$ - main effect of the i-th genotype of gilts,

$\beta_{\mathrm{j}}$ - main effect of the $\mathrm{j}$-th level of fatness or level of muscularity of gilts,

$\varepsilon_{\mathrm{ijkl}}$ - random experimental error normally distributed with zero mean and variance $\sigma^{2}$.

\section{Results}

Figure 1 shows the degree of fatness and muscularity of gilts taking part in the experiment. The highest backfat thickness at both points was noted for hybrid gilts $[\mathrm{L} \times \mathrm{LW}](\mathrm{P} \leq 0.01)$. A relatively high value for this parameter was also quoted for $\mathrm{L}$ gilts $(\mathrm{P} \leq 0.05)$. The smallest area of fat over the LD muscle, compared to $[\mathrm{L} \times \mathrm{LW}]$ and $\mathrm{L}$ gilts was seen in LW gilts $(\mathrm{P} \leq 0.05$; $\mathrm{P} \leq 0.01)$. There was a very clear difference between the amount of Longissimus dorsi muscle in $[\mathrm{L} \times \mathrm{LW}]$ gilts, and LW gilts $(\mathrm{P} \leq 0.01)$. Hybrid gilts, in comparison with purebred gilts, were characterised by a much greater width of the LD muscle $(\mathrm{P} \leq 0.01)$. The smallest area of the LD muscle was recorded for $\mathrm{L}$ gilts $(\mathrm{P} \leq 0.01)$, while the highest values of this parameter, in conjunction with $\mathrm{L}$ and $\mathrm{LW}$ gilts, were observed for hybrid gilts $[\mathrm{L} \times \mathrm{LW}](\mathrm{P} \leq 0.05 ; \mathrm{P} \leq 0.01)$.

The effect of the fatness and muscularity of gilts on the number of piglets born alive is presented in Table 1. Definitely more statistically validated differences in the number of piglets born alive were observed in the case of the parameters defining fatness, namely $\mathrm{BF}_{1}, \mathrm{BF}_{2}$, and $\mathrm{BFA}$. Gilts with the thickest of dorsal backfat $\left(\mathrm{BF}_{1}>25 \mathrm{~mm} ; \mathrm{BF}_{2}>20 \mathrm{~mm}\right)$, regardless of genotype achieved the highest number of alive piglets (all differences statistically proven on the level $\mathrm{P} \leq 0.05$ or $\mathrm{P} \leq 0.01$ ). Purebred gilts and hybrid gilts with the genotype $[\mathrm{L} \times \mathrm{LW}]$, which had the lowest surface of the fat over the LD muscle $\left(<20 \mathrm{~cm}^{2}\right)$, bore the least alive piglets $(\mathrm{P} \leq 0.05 ; \mathrm{P} \leq 0.01)$. Parameters defining the musculature of gilts, i.e. HLD, WLD and LDA, to a lesser degree determined the number of live-born piglets. It has been shown that the hybrid gilts [L $\times \mathrm{LW}$, characterised by highest $(>60 \mathrm{~mm})$ and widest $(>135 \mathrm{~mm})$ size of Logissimus dorsi muscle, with an area greater than $70 \mathrm{~cm}^{2}$, bore more alive piglets $(\mathrm{P} \leq 0.05 ; \mathrm{P} \leq 0.01)$. It is worth noting that for the $\mathrm{L}$ and $\mathrm{LW}$ gilts it was not statistically confirmed that a change in the degree of muscularity may determine the number of live-born piglets $(\mathrm{P}>0.05)$.

Table 2 shows the influence of the degree of fatness and muscularity of gilts on the average weight of piglets at birth. The lowest weight at birth was noted in piglets born by LW gilts, which at the time of insemination had the thinnest backfat $\left(\mathrm{BF}_{1}<20 \mathrm{~mm}\right.$; $\left.\mathrm{BF}_{2}<15 \mathrm{~mm}\right)(\mathrm{P} \leq 0.05 ; \mathrm{P} \leq 0.01)$. The heaviest piglets were born by $[\mathrm{L} \times \mathrm{LW}]$ gilts, characterised by the highest surface of fat over the Longissimus dorsi muscle $\left(>30 \mathrm{~cm}^{2}\right)(\mathrm{P} \leq 0.05 ; \mathrm{P} \leq 0.01)$. In the case of hybrid gilts, it was observed that higher LD muscle parameters, namely the height, width and surface area, 
increase the birth-weight of the piglets. Piglets born from $[\mathrm{L} \times \mathrm{LW}]$ gilts characterised by the surface of the LD muscle in excess of $70 \mathrm{~cm}^{2}(\mathrm{P} \leq 0.05 ; \mathrm{P} \leq 0.01)$ were the heaviest of all. It should be noted that in LW gilts the height, width, and surface of Longissimus dorsi muscle did not affect the average weight of the piglets at birth $(\mathrm{P}>0.05)$.

The effect of the fatness and muscularity of gilts on the number of piglets at weaning is presented in Table 3. The smallest number of piglets at weaning was recorded in $\mathrm{L}$ and $\mathrm{LW}$ gilts, characterised by the thinnest backfat thickness $\left(\mathrm{BF}_{1}<20 \mathrm{~mm} ; \mathrm{BF}_{2}<15 \mathrm{~mm}\right)$ $(\mathrm{P} \leq 0.05)$. A similar observation was noted for the surface of the fat over the LD muscle. The least piglets were weaned from pure breed gilts with BFA less than $20 \mathrm{~cm}^{2}(\mathrm{P} \leq 0.05 ; \mathrm{P} \leq 0.01)$. The largest number of piglets at weaning, taking into account the genotype, were observed in hybrid gilts [L $\times \mathrm{LW}]$ characterised by the highest degree of muscularity (HLD $>60 \mathrm{~mm}$; WLD $>135 \mathrm{~mm}$; LDA $\left.>70 \mathrm{~cm}^{2}\right)(\mathrm{P} \leq 0.05 ; \mathrm{P} \leq 0.01)$. It should be noted that the analysis of data concerning the number of piglets at weaning showed no statistically validated difference for the parameters of HLD, WLD and LDA, defining the musculature of $\mathrm{L}$ and $\mathrm{LW}$ gilts during the first insemination $(\mathrm{P}>0.05)$.
Table 4 demonstrates the effect of the degree of fatness and muscularity of gilts on the average weight of piglets at weaning. $\mathrm{LW}$ according to $\mathrm{BF}_{1}$ gilts bore the lightest piglets $(\mathrm{P} \leq 0.01)$. The lowest weight of piglets at weaning was listed in $\mathrm{L}$ gilts for $\mathrm{BF}_{2}$ parameter $(\mathrm{P} \leq 0.05)$. Hybrid gilts $[\mathrm{L} \times \mathrm{LW}]$ weaned the heaviest piglets regardless of the area of fat over the Longissimus dorsi muscle $(\mathrm{P} \leq 0.05 ; \mathrm{P} \leq 0.01)$. Statistical analysis confirmed that the increase in the area of fat over the LD muscle had a significant effect on increasing the weight of the piglets at weaning, both for gilts $\mathrm{L}$ and $\mathrm{LW}$ purebred, as well as $[\mathrm{L} \times \mathrm{LW}]$ hybrid gilts $(\mathrm{P} \leq 0.05 ; \mathrm{P} \leq 0.01)$. The lightest piglets were weaned by $\mathrm{L}$ gilts which a Longissimus dorsi muscle height of less than $55 \mathrm{~mm}(\mathrm{P} \leq 0.05)$. The heaviest piglets were weaned by the $[\mathrm{L} \times \mathrm{LW}]$ gilts, with Longissimus dorsi muscle ranging from 55 to 60 $\mathrm{mm}(\mathrm{P} \leq 0.01)$. Piglets born from pure breed gilts $\mathrm{L}$ and LW were much lighter in comparison with piglets born from hybrid gilts $[\mathrm{L} \times \mathrm{LW}]$, which confirms, among others, the analysis of the LD muscle area $(\mathrm{P} \leq 0.01)$. It is worth noting that in the case of L gilts the degree of muscularity had no effect on the average weight of piglets at weaning (HLD, $\mathrm{P}>0.05 ; \mathrm{WLD}, \mathrm{P}>0.05$; LDA, $\mathrm{P}>0.05$ )
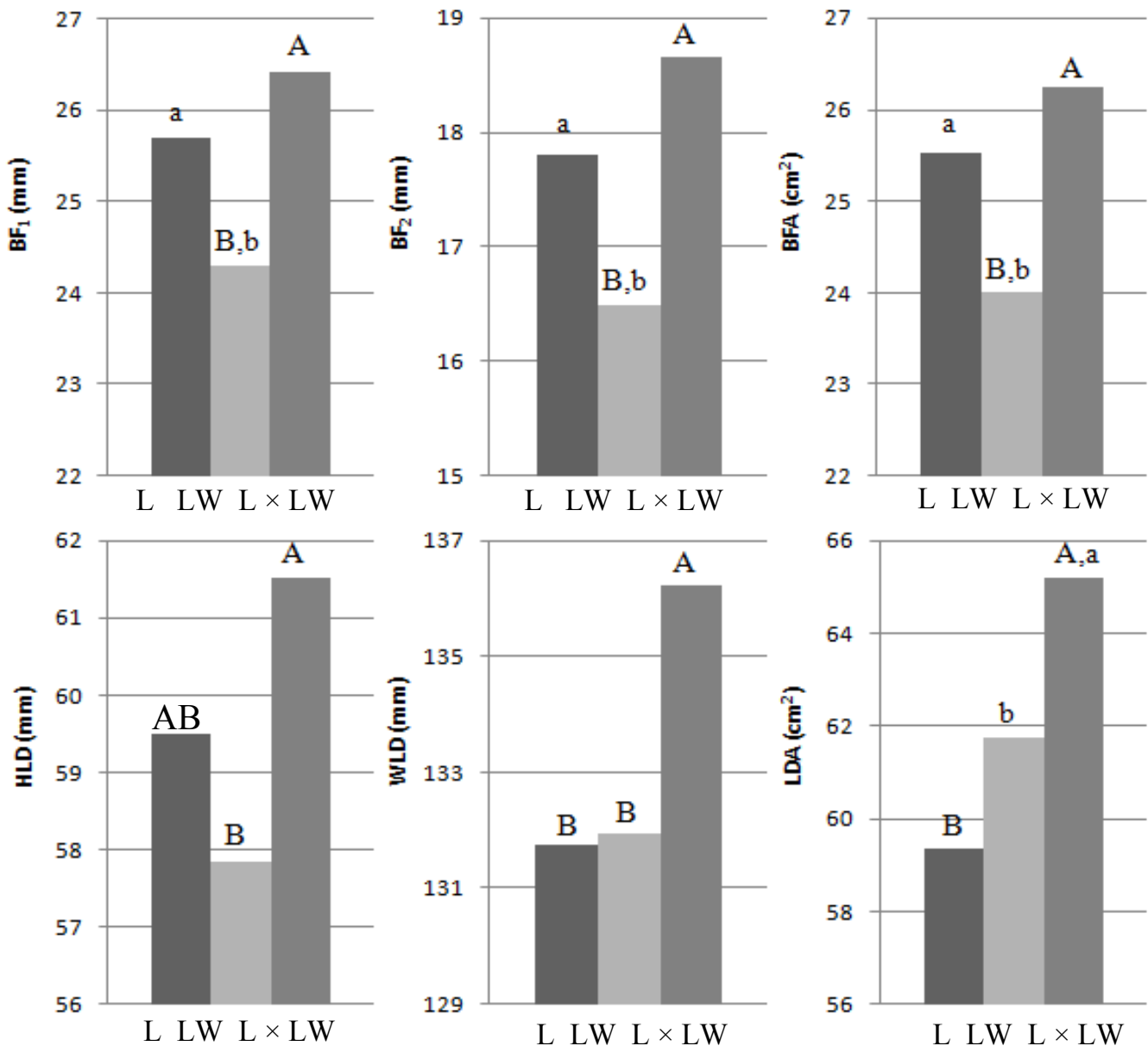

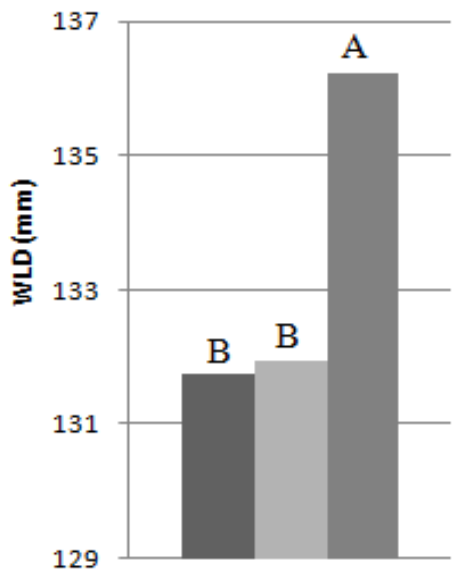

L LW $\mathrm{L} \times \mathrm{LW}$

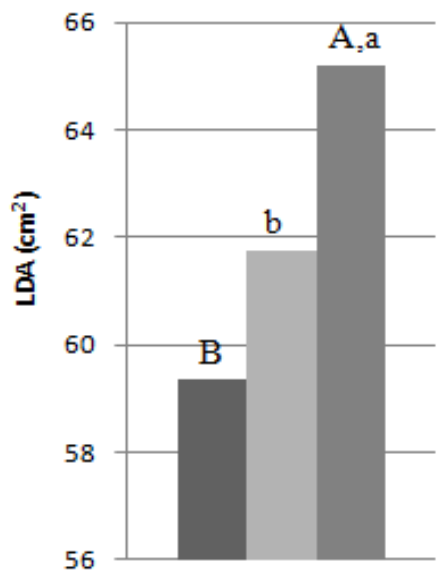

L LW $\mathrm{L} \times \mathrm{LW}$

Figure 1. The degree of fatness and muscularity of gilts with different genotypes. L - Landrace, LW - Large White, $\mathrm{L} \times \mathrm{LW}$ - Landrace $\times$ Large White; $\mathrm{BF}_{1}$ - backfat thickness measured at the last rib, $3 \mathrm{~cm}$ from the midline of the spine; $\mathrm{BF}_{2}$ - backfat thickness measured at the last rib, $8 \mathrm{~cm}$ from the midline of the spine; BFA - cross-sectional area of fat on the surface of the LD muscle; HLD - height of the LD muscle; WLD - width of the LD muscle; LDA cross-sectional area of the LD muscle. ${ }^{a, b}$ indicate statistically significant differences between genotypes, at $\mathrm{P} \leq 0.05$. $\mathrm{A}, \mathrm{B}$ indicate statistically highly significant differences between genotypes, at $\mathrm{P} \leq 0.01$. 
Table 1. The influence of fatness and muscularity of gilts on the number of piglets born alive.

\begin{tabular}{|c|c|c|c|c|}
\hline \multirow{2}{*}{ Measurement } & \multirow{2}{*}{ Level } & \multicolumn{3}{|c|}{ Number of piglets born alive (n) } \\
\hline & & $\begin{array}{c}\mathrm{L} \\
\mathrm{n}=154\end{array}$ & $\begin{array}{c}\text { LW } \\
n=154\end{array}$ & $\begin{array}{c}{[\mathrm{L} \times \mathrm{LW}]} \\
\mathrm{n}=154\end{array}$ \\
\hline $\mathrm{BF}_{1}$ & $\begin{array}{c}<20 \mathrm{~mm} \\
20-25 \mathrm{~mm} \\
>25 \mathrm{~mm}\end{array}$ & $\begin{array}{r}9.02^{\mathrm{b}} \pm 0.57 \\
9.50 \pm 0.48 \\
9.83^{\mathrm{a}, \mathrm{y}} \pm 0.40\end{array}$ & $\begin{array}{r}9.00^{\mathrm{b}} \pm 0.58 \\
9.46 \pm 0.50 \\
9.80^{\mathrm{a}, \mathrm{y}} \pm 0.43\end{array}$ & $\begin{array}{r}9.51^{\mathrm{B}} \pm 0.45 \\
9.84^{\mathrm{b}} \pm 0.40 \\
10.64^{\mathrm{A}, \mathrm{a}, \mathrm{x}} \pm 0.35\end{array}$ \\
\hline $\mathrm{BF}_{2}$ & $\begin{array}{c}<15 \mathrm{~mm} \\
15-20 \mathrm{~mm} \\
>20 \mathrm{~mm}\end{array}$ & $\begin{array}{r}9.11^{\mathrm{b}} \pm 0.60 \\
9.58 \pm 0.53 \\
9.91^{\mathrm{a}, \mathrm{y}} \pm 0.42\end{array}$ & $\begin{array}{r}9.10^{\mathrm{b}} \pm 0.65 \\
9.60 \pm 0.56 \\
9.93^{\mathrm{a}, \mathrm{y}} \pm 0.50\end{array}$ & $\begin{array}{r}9.60^{\mathrm{B}} \pm 0.49 \\
9.94^{\mathrm{b}} \pm 0.41 \\
10.75^{\mathrm{A}, \mathrm{a}, \mathrm{x}} \pm 0.33\end{array}$ \\
\hline BFA & $\begin{array}{c}<20 \mathrm{~cm}^{2} \\
20-30 \mathrm{~cm}^{2} \\
>30 \mathrm{~cm}^{2}\end{array}$ & $\begin{array}{r}9.15^{\mathrm{B}, \mathrm{b}} \pm 0.59 \\
9.95^{\mathrm{a}} \pm 0.50 \\
10.16^{\mathrm{A}} \pm 0.38\end{array}$ & $\begin{array}{r}9.19^{\mathrm{b}} \pm 0.61 \\
10.00^{\mathrm{a}} \pm 0.53 \\
10.08^{\mathrm{a}, \mathrm{y}} \pm 0.37\end{array}$ & $\begin{array}{r}9.77^{\mathrm{B}} \pm 0.52 \\
10.08^{\mathrm{b}} \pm 0.47 \\
10.89^{\mathrm{A}, \mathrm{a}, \mathrm{x}} \pm 0.30\end{array}$ \\
\hline HLD & $\begin{array}{c}<55 \mathrm{~mm} \\
55-60 \mathrm{~mm} \\
>60 \mathrm{~mm}\end{array}$ & $\begin{array}{r}9.20 \pm 0.54 \\
9.49 \pm 0.50 \\
9.94 \pm 0.43\end{array}$ & $\begin{array}{r}9.15 \pm 0.57 \\
9.40 \pm 0.53 \\
9.89^{\mathrm{y}} \pm 0.43\end{array}$ & $\begin{aligned} 9.90^{\mathrm{b}} & \pm 0.43 \\
9.99 & \pm 0.39 \\
10.70^{\mathrm{a}, \mathrm{x}} & \pm 0.34\end{aligned}$ \\
\hline WLD & $\begin{array}{c}<130 \mathrm{~mm} \\
130-135 \mathrm{~mm} \\
>135 \mathrm{~mm}\end{array}$ & $\begin{array}{l}9.13 \pm 0.63 \\
9.40 \pm 0.52 \\
9.89 \pm 0.44\end{array}$ & $\begin{array}{r}9.09 \pm 0.66 \\
9.37 \pm 0.57 \\
9.84^{\mathrm{y}} \pm 0.49\end{array}$ & $\begin{array}{r}9.83^{\mathrm{b}} \pm, 0.45 \\
9.90 \pm, 0.41 \\
10.65^{\mathrm{a}, \mathrm{x}} \pm, 0.37\end{array}$ \\
\hline LDA & $\begin{array}{c}<60 \mathrm{~cm}^{2} \\
60-70 \mathrm{~cm}^{2} \\
>70 \mathrm{~cm}^{2}\end{array}$ & $\begin{array}{l}9.18 \pm 0.56 \\
9.49 \pm 0.49 \\
9.97 \pm 0.40\end{array}$ & $\begin{array}{r}9.14 \pm 0.58 \\
9.41 \pm 0.50 \\
9.70^{\mathrm{Y}} \pm 0.48\end{array}$ & $\begin{array}{r}9.90^{\mathrm{b}} \pm, 0.45 \\
9.95 \pm, 0.42 \\
10.72^{\mathrm{a} ;, \mathrm{X}} \pm, 0.35\end{array}$ \\
\hline
\end{tabular}

$\overline{\mathrm{a}, \mathrm{b}}$ indicate statistically significant differences between levels of measurement, at $\mathrm{P} \leq 0.05 .{ }^{\mathrm{A}, \mathrm{B}}$ indicate statistically highly significant differences between levels of measurement, at $\mathrm{P} \leq 0.01$. ${ }^{\mathrm{x}, \mathrm{y}}$ indicate statistically significant differences between genotypes, at $\mathrm{P} \leq 0.05$. ${ }^{\mathrm{X}, \mathrm{Y}}$ indicate statistically highly significant differences between genotypes, at $\mathrm{P} \leq 0.01$. L - Landrace, $\mathrm{LW}$ - Large White, $\mathrm{L} \times \mathrm{LW}$ - Landrace $\times$ Large White; $\mathrm{BF}_{1}$ - backfat thickness measured at the last rib, $3 \mathrm{~cm}$ from the midline of the spine; $\mathrm{BF}_{2}$ - backfat thickness measured at the last rib, $8 \mathrm{~cm}$ from the midline of the spine; BFA - cross-sectional area of fat on the surface of the LD muscle; HLD - height of the LD muscle; WLD - width of the LD muscle; LDA - cross-sectional area of the LD muscle.

Table 2. The influence of fatness and muscularity of gilts on the average piglet birth weight.

\begin{tabular}{|c|c|c|c|c|}
\hline \multirow{2}{*}{ Measurement } & \multirow{2}{*}{ Level } & \multicolumn{3}{|c|}{ Average birth piglet weight $(\mathrm{kg})$} \\
\hline & & $\begin{array}{c}\mathrm{L} \\
\mathrm{n}=154\end{array}$ & $\begin{array}{c}\mathrm{LW} \\
\mathrm{n}=154\end{array}$ & $\begin{array}{c}{[\mathrm{L} \times \mathrm{LW}]} \\
\mathrm{n}=154\end{array}$ \\
\hline \multirow{3}{*}{$\mathrm{BF}_{1}$} & $<20 \mathrm{~mm}$ & $1.35^{\mathrm{y}} \pm 0.28$ & $1.33^{\mathrm{b}, \mathrm{Y}} \pm 0.30$ & $1.45^{\mathrm{b}, \mathrm{X}, \mathrm{x}} \pm 0.27$ \\
\hline & $20-25 \mathrm{~mm}$ & $1.40 \pm 0.25$ & $1.38^{\mathrm{y}} \pm 0.27$ & $1.49^{\mathrm{x}} \pm 0.24$ \\
\hline & $>25 \mathrm{~mm}$ & $1.44^{\mathrm{y}} \pm 0.21$ & $1.43^{\mathrm{a}, \mathrm{Y}} \pm 0.23$ & $1.55^{\mathrm{a}, \mathrm{X}, \mathrm{x}} \pm 0.19$ \\
\hline \multirow{3}{*}{$\mathrm{BF}_{2}$} & $<15 \mathrm{~mm}$ & $1.32^{\mathrm{B}, \mathrm{y}} \pm 0.31$ & $1.30^{\mathrm{B}, \mathrm{Y}} \pm 0.35$ & $1.42^{\mathrm{b}, \mathrm{X}, \mathrm{x}} \pm 0.28$ \\
\hline & $15-20 \mathrm{~mm}$ & $1.36^{\mathrm{y}} \pm 0.29$ & $1.35^{\mathrm{Y}} \pm 0.30$ & $1.47^{\mathrm{X}, \mathrm{x}} \pm 0.26$ \\
\hline & $>20 \mathrm{~mm}$ & $1.44^{\mathrm{A}} \pm 0.23$ & $1.42^{\mathrm{A}, \mathrm{y}} \pm 0.20$ & $1.52^{\mathrm{a}, \mathrm{x}} \pm 0.20$ \\
\hline \multirow{3}{*}{ BFA } & $<20 \mathrm{~cm}^{2}$ & $1.30^{\mathrm{B}, \mathrm{b}, \mathrm{y}} \pm 0.32$ & $1.31^{\mathrm{B}} \pm 0.30$ & $1.40^{\mathrm{B}, \mathrm{x}} \pm 0.26$ \\
\hline & $20-30 \mathrm{~cm}^{2}$ & $1.40^{\mathrm{a}} \pm 0.27$ & $1.39 \pm 0.27$ & $1.48 \pm 0.21$ \\
\hline & $>30 \mathrm{~cm}^{2}$ & $1.45^{\mathrm{A} ; \mathrm{y}} \pm 0.25$ & $1.43^{\mathrm{A}, \mathrm{Y}} \pm 0.23$ & $1.56^{\mathrm{A}, \mathrm{X}, \mathrm{x}} \pm 0.18$ \\
\hline \multirow{3}{*}{ HLD } & $<55 \mathrm{~mm}$ & $1.36 \pm 0.29$ & $1.34 \pm 0.28$ & $1.41^{\mathrm{B}} \pm 0.24$ \\
\hline & $55-60 \mathrm{~mm}$ & $1.42 \pm 0.26$ & $1.40 \pm 0.24$ & $1.46^{\mathrm{B}} \pm 0.22$ \\
\hline & $>60 \mathrm{~mm}$ & $1.45^{\mathrm{Y}} \pm 0.25$ & $1.43^{\mathrm{Y}} \pm 0.23$ & $1.58^{\mathrm{A}, \mathrm{X}} \pm 0.17$ \\
\hline \multirow{3}{*}{ WLD } & $<130 \mathrm{~mm}$ & $1.39^{\mathrm{y}} \pm 0.28$ & $1.40 \pm 0.26$ & $1.49^{\mathrm{b}, \mathrm{x}} \pm 0.20$ \\
\hline & $130-135 \mathrm{~mm}$ & $1.45^{\mathrm{y}} \pm 0.22$ & $1.46 \pm 0.23$ & $1.55^{\mathrm{x}} \pm 0.17$ \\
\hline & $>135 \mathrm{~mm}$ & $1.48^{\mathrm{y}} \pm 0.20$ & $1.49^{\mathrm{y}} \pm 0.20$ & $1.59^{\mathrm{a}, \mathrm{x}} \pm 0.15$ \\
\hline \multirow{3}{*}{ LDA } & $<60 \mathrm{~cm}^{2}$ & $1.38^{\mathrm{b}} \pm 0.28$ & $1.41 \pm 0.26$ & $1.47^{\mathrm{B}} \pm 0.24$ \\
\hline & $60-70 \mathrm{~cm}^{2}$ & $1.44 \pm 0.24$ & $1.45 \pm 0.23$ & $1.53 \pm 0.16$ \\
\hline & $>70 \mathrm{~cm}^{2}$ & $1.49^{\mathrm{a}, \mathrm{y}} \pm 0.19$ & $1.50^{\mathrm{y}} \pm 0.19$ & $1.60^{\mathrm{A}, \mathrm{x}} \pm 0.13$ \\
\hline
\end{tabular}

${ }_{\mathrm{a}, \mathrm{b}}$ indicate statistically significant differences between levels of measurement, at $\mathrm{P} \leq 0.05 .{ }^{\mathrm{A}, \mathrm{B}}$ indicate statistically highly significant differences between levels of measurement, at $\mathrm{P} \leq 0.01$. $^{\mathrm{x}, \mathrm{y}}$ indicate statistically significant differences between genotypes, at $\mathrm{P} \leq 0.05$. ${ }_{\mathrm{X}, \mathrm{Y}}$ indicate statistically highly significant differences between genotypes, at $\mathrm{P} \leq 0.01$. L - Landrace, LW - Large White, $\mathrm{L} \times \mathrm{LW}$ - Landrace $\times$ Large White; $\mathrm{BF}_{1}$ - backfat thickness measured at the last rib, $3 \mathrm{~cm}$ from the midline of the spine; $\mathrm{BF}_{2}$ - backfat thickness measured at the last rib, $8 \mathrm{~cm}$ from the midline of the spine; BFA - cross-sectional area of fat on the surface of the LD muscle; HLD - height of the LD muscle; WLD - width of the LD muscle; LDA - cross-sectional area of the LD muscle. 
Table 3. The influence of fatness and muscularity of gilts on the number of weaned piglets.

\begin{tabular}{|c|c|c|c|c|}
\hline \multirow{2}{*}{ Measurement } & \multirow{2}{*}{ Level } & \multicolumn{3}{|c|}{ Number of piglets weaned at 28 days (n) } \\
\hline & & $\begin{array}{c}\mathrm{L} \\
\mathrm{n}=154\end{array}$ & $\begin{array}{c}\mathrm{LW} \\
\mathrm{n}=154\end{array}$ & $\begin{array}{c}{[\mathrm{L} \times \mathrm{LW}]} \\
\mathrm{n}=154\end{array}$ \\
\hline \multirow{3}{*}{$\mathrm{BF}_{1}$} & $<20 \mathrm{~mm}$ & $8.84^{\mathrm{b}} \pm 0.37$ & $8.85^{\mathrm{b}} \pm 0.40$ & $9.33^{\mathrm{B}} \pm 0.39$ \\
\hline & $20-25 \mathrm{~mm}$ & $9.23 \pm 0.28$ & $9.30 \pm 0.34$ & $9.65^{b} \pm 0.35$ \\
\hline & $>25 \mathrm{~mm}$ & $9.65^{\mathrm{a}, \mathrm{y}} \pm 0.24$ & $9.66^{\mathrm{a}, \mathrm{y}} \pm 0.30$ & $10.48^{\mathrm{A}, \mathrm{a}, \mathrm{x}} \pm 0.25$ \\
\hline \multirow{3}{*}{$\mathrm{BF}_{2}$} & $<15 \mathrm{~mm}$ & $8.90^{\mathrm{b}} \pm 0.40$ & $8.94^{\mathrm{b}} \pm 0.42$ & $9.45^{\mathrm{B}} \pm 0.40$ \\
\hline & $15-20 \mathrm{~mm}$ & $9.40 \pm 0.35$ & $9.43 \pm 0.36$ & $9.79^{b} \pm 0.34$ \\
\hline & $>20 \mathrm{~mm}$ & $9.70^{\mathrm{a}, \mathrm{y}} \pm 0.31$ & $9.75^{\mathrm{a}, \mathrm{y}} \pm 0.32$ & $10.61^{\mathrm{A}, \mathrm{a}, \mathrm{x}} \pm 0.23$ \\
\hline \multirow{3}{*}{ BFA } & $<20 \mathrm{~cm}^{2}$ & $8.96^{\mathrm{B}, \mathrm{b}} \pm 0.38$ & $9.03^{\mathrm{b}} \pm 0.44$ & $9.60^{\mathrm{B}} \pm 0.32$ \\
\hline & $20-30 \mathrm{~cm}^{2}$ & $9.77^{\mathrm{a}} \pm 0.34$ & $9.85^{\mathrm{a}} \pm 0.27$ & $9.88^{\mathrm{b}} \pm 0.29$ \\
\hline & $>30 \mathrm{~cm}^{2}$ & $9.99^{\mathrm{A}} \pm 0.28$ & $9.89^{\mathrm{a}, \mathrm{y}} \pm 0.25$ & $10.70^{\mathrm{A}, \mathrm{a}, \mathrm{x}} \pm 0.20$ \\
\hline \multirow{3}{*}{ HLD } & $<55 \mathrm{~mm}$ & $9.01 \pm 0.43$ & $9.01 \pm 0.43$ & $9.71^{\mathrm{b}} \pm 0.36$ \\
\hline & $55-60 \mathrm{~mm}$ & $9.27 \pm 0.37$ & $9.24 \pm 0.38$ & $9.80 \pm 0.34$ \\
\hline & $>60 \mathrm{~mm}$ & $9.78 \pm 0.33$ & $9.73^{y} \pm 0.31$ & $10.53^{\mathrm{a}, \mathrm{x}} \pm 0.25$ \\
\hline \multirow{3}{*}{ WLD } & $<130 \mathrm{~mm}$ & $8.95 \pm 0.44$ & $8.90 \pm 0.46$ & $9.65^{b} \pm 0.39$ \\
\hline & $130-135 \mathrm{~mm}$ & $9.19 \pm 0.38$ & $9.15 \pm 0.40$ & $9.74 \pm 0.36$ \\
\hline & $>135 \mathrm{~mm}$ & $9.66^{\mathrm{y}} \pm 0.32$ & $9.61^{\mathrm{y}} \pm 0.35$ & $10.48^{\mathrm{a}, \mathrm{x}} \pm 0.30$ \\
\hline \multirow{3}{*}{ LDA } & $<60 \mathrm{~cm}^{2}$ & $9.03 \pm 0.43$ & $9.00 \pm 0.41$ & $9.71^{\mathrm{b}} \pm 0.38$ \\
\hline & $60-70 \mathrm{~cm}^{2}$ & $9.32 \pm 0.36$ & $9.28 \pm 0.36$ & $9.79 \pm 0.35$ \\
\hline & $>70 \mathrm{~cm}^{2}$ & $9.80 \pm 0.29$ & $9.54^{\mathrm{Y}} \pm 0.30$ & $10.55^{\mathrm{a}, \mathrm{X}} \pm 0.24$ \\
\hline
\end{tabular}

$\overline{\mathrm{a}, \mathrm{b}}$ indicate statistically significant differences between levels of measurement, at $\mathrm{P} \leq 0.05 .{ }^{\mathrm{A}, \mathrm{B}}$ indicate statistically highly significant differences between levels of measurement, at $\mathrm{P} \leq 0.01$. ${ }^{\mathrm{x}, \mathrm{y}}$ indicate statistically significant differences between genotypes, at $\mathrm{P} \leq 0.05$. ${ }^{\mathrm{X}, \mathrm{Y}}$ indicate statistically highly significant differences between genotypes, at $\mathrm{P} \leq 0.01$. L - Landrace, $\mathrm{LW}$ - Large White, $\mathrm{L} \times \mathrm{LW}$ - Landrace $\times$ Large White; $\mathrm{BF}_{1}-$ backfat thickness measured at the last rib, $3 \mathrm{~cm}$ from the midline of the spine; $\mathrm{BF}_{2}$ - backfat thickness measured at the last rib, $8 \mathrm{~cm}$ from the midline of the spine; BFA - cross-sectional area of fat on the surface of the LD muscle; HLD - height of the LD muscle; WLD - width of the LD muscle; LDA - cross-sectional area of the LD muscle.

Table 4. The influence of fatness and muscularity of gilts on the weaned piglet weight.

\begin{tabular}{|c|c|c|c|c|}
\hline \multirow{2}{*}{ Measurement } & \multirow{2}{*}{ Level } & \multicolumn{3}{|c|}{ Average weaned piglet weight $(\mathrm{kg})$} \\
\hline & & $\begin{array}{c}\mathrm{L} \\
\mathrm{n}=154\end{array}$ & $\begin{array}{c}\mathrm{LW} \\
\mathrm{n}=154\end{array}$ & $\begin{array}{c}{[\mathrm{L} \times \mathrm{LW}]} \\
\mathrm{n}=154\end{array}$ \\
\hline \multirow{3}{*}{$\mathrm{BF}_{1}$} & $<20 \mathrm{~mm}$ & $8.33^{\mathrm{b}, \mathrm{y}} \pm 0.45$ & $8.30^{\mathrm{Y}} \pm 0.47$ & $8.44^{\mathrm{b}, X, \mathrm{x}} \pm 0.35$ \\
\hline & $20-25 \mathrm{~mm}$ & $8.39 \pm 0.38$ & $8.34^{\mathrm{Y}} \pm 0.44$ & $8.48^{\mathrm{X}} \pm 0.31$ \\
\hline & $>25 \mathrm{~mm}$ & $8.43^{\mathrm{a}, \mathrm{Y}} \pm 0.31$ & $8.39^{\mathrm{Y}} \pm 0.39$ & $8.55^{\mathrm{a}, \mathrm{X}} \pm 0.20$ \\
\hline \multirow{3}{*}{$\mathrm{BF}_{2}$} & $<15 \mathrm{~mm}$ & $8.36^{\mathrm{b}, \mathrm{y}} \pm 0.43$ & $8.39 \pm 0.38$ & $8.46^{\mathrm{B}, \mathrm{x}} \pm 0.33$ \\
\hline & $15-20 \mathrm{~mm}$ & $8.40 \pm 0.35$ & $8.43 \pm 0.33$ & $8.49 \pm 0.30$ \\
\hline & $>20 \mathrm{~mm}$ & $8.47^{\mathrm{a}, \mathrm{y}} \pm 0.30$ & $8.48^{y} \pm 0.29$ & $8.58^{\mathrm{A}, \mathrm{x}} \pm 0.18$ \\
\hline \multirow{3}{*}{ BFA } & $<20 \mathrm{~cm}^{2}$ & $8.39^{\mathrm{b}, \mathrm{y}} \pm 0.40$ & $8.41^{b} \pm 0.38$ & $8.50^{\mathrm{B}, \mathrm{x}} \pm 0.25$ \\
\hline & $20-30 \mathrm{~cm}^{2}$ & $8.44^{\mathrm{Y}} \pm 0.35$ & $8.47 \pm 0.31$ & $8.56^{\mathrm{X}} \pm 0.21$ \\
\hline & $>30 \mathrm{~cm}^{2}$ & $8.49^{\mathrm{a}, \mathrm{Y}} \pm 0.28$ & $8.51^{\mathrm{a}, \mathrm{Y}} \pm 0.23$ & $8.63^{\mathrm{A}, \mathrm{X}} \pm 0.15$ \\
\hline \multirow{3}{*}{ HLD } & $<55 \mathrm{~mm}$ & $8.38^{\mathrm{y}} \pm 0.38$ & $8.41 \pm 0.32$ & $8.48^{\mathrm{B}, \mathrm{x}} \pm 0.28$ \\
\hline & $55-60 \mathrm{~mm}$ & $8.41^{\mathrm{Y}} \pm 0.28$ & $8.45^{\mathrm{Y}} \pm 0.25$ & $8.60^{\mathrm{A}, \mathrm{X}} \pm 0.16$ \\
\hline & $>60 \mathrm{~mm}$ & $8.47 \pm 0.25$ & $8.50 \pm 0.21$ & $8.55 \pm 0.18$ \\
\hline \multirow{3}{*}{ WLD } & $<130 \mathrm{~mm}$ & $8.40 \pm 0.37$ & $8.43^{b} \pm 0.34$ & $8.49 \pm 0.23$ \\
\hline & $130-135 \mathrm{~mm}$ & $8.45 \pm 0.34$ & $8.48 \pm 0.30$ & $8.53 \pm 0.18$ \\
\hline & $>135 \mathrm{~mm}$ & $8.49 \pm 0.25$ & $8.53^{\mathrm{a}} \pm 0.21$ & $8.50 \pm 0.20$ \\
\hline \multirow{3}{*}{ LDA } & $<60 \mathrm{~cm}^{2}$ & $8.36 \pm 0.40$ & $8.38 \pm 0.35$ & $8.45^{\mathrm{b}} \pm 0.32$ \\
\hline & $60-70 \mathrm{~cm}^{2}$ & $8.40^{\mathrm{Y}} \pm 0.35$ & $8.42^{\mathrm{Y}} \pm 0.31$ & $8.56^{\mathrm{a}, \mathrm{X}} \pm 0.20$ \\
\hline & $>70 \mathrm{~cm}^{2}$ & $8.44 \pm 0.28$ & $8.46 \pm 0.23$ & $8.49 \pm 0.23$ \\
\hline
\end{tabular}

${ }_{\mathrm{a}, \mathrm{b}}$ indicate statistically significant differences between levels of measurement, at $\mathrm{P} \leq 0.05 .{ }^{\mathrm{A}, \mathrm{B}}$ indicate statistically highly significant differences between levels of measurement, at $\mathrm{P} \leq 0.01$. ${ }^{\mathrm{x}, \mathrm{y}}$ indicate statistically significant differences between genotypes, at $\mathrm{P} \leq 0.05$. $\mathrm{X}, \mathrm{Y}$ indicate statistically highly significant differences between genotypes, at $\mathrm{P} \leq 0.01$. L - Landrace, LW - Large White, $\mathrm{L} \times \mathrm{LW}-$ Landrace $\times$ Large White; $\mathrm{BF}_{1}-\mathrm{backfat}$ thickness measured at the last rib, $3 \mathrm{~cm}$ from the midline of the spine; $\mathrm{BF}_{2}$ - backfat thickness measured at the last rib, $8 \mathrm{~cm}$ from the midline of the spine; BFA - cross-sectional area of fat on the surface of the LD muscle; HLD height of the LD muscle; WLD - width of the LD muscle; LDA - cross-sectional area of the LD muscle. 


\section{Discussion}

The effect of fatness and muscularity on the reproductive performance parameters of sows is often indicated in the literature (Zhang et al., 2000; Holm et al., 2004; Čechova and Tvrdoň, 2006; Mijatović et al., 2009; Szulc et al., 2013), but there is not enough data, which discusses whether and how these parameters measured during the first insemination affect the reproductive indicators of gilts.

Body weight of gilts were not analysed because according to the studies relating to the dissection of pig carcasses, more reliable indicator is the analysis of individual parameters of muscle and fat. Due to differences in anatomical structure, carcasses with the same weight may differ in dimensions of fat and muscle or tissues composition (Marcoux et al., 2007; Duziński et al., 2015; Knecht and Duziński, 2016). Additionally, average body weight among genotypes was similar, with no statistically proven differences $(\mathrm{P}>0.05)$.

In our study, we have shown both that the reproductive performance of gilts is significantly affected by the fatness degree during insemination, and that the level of muscularity has no such great significance (except for the hybrid gilts). The increase in the degree of fatness and additionally in the case of gilts $[\mathrm{L} \times \mathrm{LW}]$ the level of muscularity during the first insemination may determine the improvement of reproductive indicators. The highest number of piglets born alive and weaned has been reported in gilts with the thickest backfat $\left(\mathrm{BF}_{1}>25 \mathrm{~mm}, \mathrm{BF}_{2}>20 \mathrm{~mm}\right)$. It is partially connected with control of proper ovulation (Gonçalves et al., 2012). However, Matysiak et al. (2010) found that the number of piglets born alive and weaning are positively correlated with the thickness of backfat respectively $r=0.31$ and $r=0.24$, which means that gilts with thicker backfat bore more piglets and weaned a higher number of piglets; and this was also observed in our study. These results may explain the two processes related to the metabolism of gilts, namely anabolism and catabolism. Holm et al. (2004) note that when energy stores are too low (gilts characterised by a lower degree of fatness during the first insemination), the development and implantation of the embryos in the uterus may not function properly, resulting in an increase in the number of embryos that experience resorption in the uterus, and as a result this contributes to a reduced number of piglets born alive. Vanroose et al. (2000) presented other factors that influence the resorption of embryos, such as viral infections, stress, poor nutrition or reproductive seasonality.

The lowest piglets birth weights were listed in gilts which were characterised by the lowest backfat thickness during insemination $\left(\mathrm{BF}_{1}<20 \mathrm{~mm}, \mathrm{BF}_{2}<15\right.$ $\mathrm{mm})$. It should be noted that a lower degree of gilt fatness during insemination may impair the development of the fetus and exert a deleterious influence on their growth. It may also affect the lower weight of the piglets at birth, which probably contributed to the worse performance of our reproductive values in this regard. Roehe (1999), Milligan et al. (2002), Wolf et al. (2008) stress that low body weight at birth is accompanied by a rise in the number of piglets born dead and an increased number of falls during rearing, which is associated with the great physiological effort demanded of gilt organism. During this period the process called catabolism is in effect, during which the stocks of energy previously stored in the form of body fat are released. Zak et al. (1998) emphasized that the metabolism of gilts, set for a long period of gestation for the deposition of energy reserves, encounters problems associated with switching in a very short period of time to use all the ingredients of feed for milk production. As a result, gilts retrieving the feed continue to use the feed for stock collection and use fat reserves as a source of components necessary for the production of milk. Rozeboom et al. (1996) suggested that the weaker pregnancy anabolism probably slows lactation in sows, which may result in the reduction of the number of piglets weaned, as a result of the insufficient production of milk. Holm et al. (2004) found that the backfat thickness, which is considered a source of energy for sows, may also have an important role in the subsequent reproductive cycles.

Szulc et al. (2013) reported that very high levels of gilt fatness during mating/insemination can lead to hormonal disorders in young females. In the case of that study, the authors noted that the gilts with the thickest dorsal backfat $(>15 \mathrm{~mm})$ bore the least alive piglets. The authors explained their results via the characteristic transformation of estradiol to estriol, a weaker estrogen that occurs in more obese females. In our study we observed the opposite effect. Gilts that had the highest backfat thickness at both points bore and weaned more piglets with very high weight at birth and weaning. Similar results were obtained in the study of Tummaruk et al. (2001).

Many authors have confirmed a very strong positive correlation between the backfat thickness, and litter size (Čechova and Buchta, 1995; Karsten et al., 2000; Chen et al., 2003). Our studies confirm that gilts with a higher backfat thickness at the time of insemination may bore more piglets, characterised by a higher weight at birth. A similar trend is also observed for the analysis of fat on the surface of the LD muscle, except that in the case of L and LW purebred gilts in order to obtain satisfactory reproductive results the insemination treatment can be carried out at BFA greater than $20 \mathrm{~cm}^{2}$. Kawecka et al. (2009) found a significant inverse relationship between the meatiness of gilts and their subsequent reproductive performance during the next three parities, which means that too large a degree of muscularity aggravates the reproduction indicators. In the case of our study an increase in the degree of muscularity as regards parameters HLD, WLD and LDA resulted in improved reproductive performance indicators, but only for hybrid gilts $[\mathrm{L} \times \mathrm{LW}]$.

The observed results may be related to the occurrence of heterosis. Hybrid gilts $[\mathrm{L} \times \mathrm{LW}]$ are characterised by the greatest degree of fatness and muscularity and achieve better results in a range of reproductive parameters, which according to Nowachowicz et al. (2009) can be explained by the 
predominance of the hybrids of the first generation over the phenotypic values of their parents. In livestock, the advantage of first generation hybrid mean values for phenotypic characteristics over those of the parents is important and this difference can be as high as $15 \%$. Zhang et al. (2000) noted that in the second generation obtained from mating animals of the first generation the heterosis effect is significantly reduced as a result of a definitely weaker interaction of genes. Slightly worse performance in hybrid gilts was demonstrated in the research published by Matysiak et al. (2010).

Our results clearly show that an appropriate level of gilt fatness during insemination can contribute to significant improvements in the efficiency of piglet production. In order to increase the number of piglets born alive, the number of piglets at weaning and the weights in these periods, it is recommended that insemination of $\mathrm{L}, \mathrm{LW}$ and $[\mathrm{L} \times \mathrm{LW}]$ gilts should occurs, when: backfat thickness measured behind the last rib $3 \mathrm{~cm}$ from the midline of the spine exceeds 25 $\mathrm{mm}$; backfat thickness measured $8 \mathrm{~cm}$ from the midline of the spine exceeds $20 \mathrm{~mm}$. Additionally, insemination of gilts with the genotype $[\mathrm{L} \times \mathrm{LW}]$ should occur when the amount of LD muscle exceeds $60 \mathrm{~mm}$, the width of the muscle is greater than $135 \mathrm{~mm}$, and its surface is greater than $70 \mathrm{~cm}^{2}$.

\section{Acknowledgments}

This work was financed by Wroclaw University of Environmental and Life Sciences, project no. WBiHZ/442/2014/SC. The authors wish to thank K. Bernhardt for revising the English version of the manuscript.

\section{References}

Barb CR, Kraeling RR, Rampacek GB, Dove CR. 1997. Metabolic changes during the transition from the fed to the acute feed-deprived state in prepuberal and mature gilts. J Anim Sci, 75:781-789.

Bidanel J, Gruand J, Legault C. 1996. Genetic variability of age and weight at puberty, ovulation rate and embryo survival in gilts and relations with production traits. Genet Sel Evol, 28:1-13.

Blicharski T, Ptak J, Snopkiewicz M (Ed.). 2014 Pigs' performance results in 2013. Warsaw, Poland: Polish Pig Breeders and Producers Association (POLSUS). pp. 5-50.

Čechova M, Buchta S. 1995. Effect of genetic antagonism between reproductive and fattening traits in pig dam breeds. In: Congress. Zěmědělstvi $v$ marginalnich podminkach. Česke Budějovice: The Congress. 291-297.

Čechova M, Tvrdoň Z. 2006. Relationships between backfat thickness and parameters of reproduction in Czech Large White sows. Arch Tierz, 49:363-369.

Chen P, Baas TJ, Mabry JW, Koehler KJ. 2003. Genetic correlations between lean growth and litter traits in U.S. Yorkshire, Duroc, Hampshire, and Landrace pigs. J Anim Sci, 81:1700-1705.

Duziński K, Lisiak D, Knecht D, Środoń S. 2015. The estimation of pork carcass primal cuts value based on backfat thickness. J Cent Eur Agric, 16:112-121.

Gonçalves PBD, Gasperin BG, Ferreira R, Santos JT. 2012. Control of ovulation in mammals. Anim Reprod, 9:354-361.

Grela ER, Skomial J (Ed.). 2014. Polish Swine Nutrition Requirements. Jabłonna, Poland: The Kielanowski Institute Animal Physiology and Nutrition. Polish Academy of Sciences. pp. 56-61.

Holm B, Bakken M, Klemetsdal G, Vangen O. 2004. Genetic correlations between reproduction and production traits in swine. J Anim Sci, 82:3458-3464.

Imboonta N, Rydhmer L, Tumwasorn S. 2007. Genetic parameters and trends for production and reproduction traits in Thai Landrace sows. Livest Sci, 111:70-79.

Karsten S, Rohe R, Schulze V, Looft H, Kalm E. 2000. Genetic association between individual feed intake during performance test and reproductions traits in pigs. Arch Tierz, 43:451-461.

Kawęcka M, Matysiak B, Kamyczek M, Delikator B. 2009. Relationships between growth, fatness and meatiness traits in gilts and their subsequent reproductive performance. Ann Anim Sci, 9:249-258.

Kim SW, Weaver AC, Shen YB, Zhao Y. 2013. Improving efficiency of sow productivity: nutrition and health. J Anim Sci Biotechnol, 4:26. doi: 10.1186/20491891-4-26.

King GJ, Macpherson JW. 1973. A comparison of two methods for boar semen collection. J Anim Sci, 36:563-565.

Knecht D, Środoń S, Duziński K. 2014a. Does a boar's season of birth determine semen parameters and reproductive performance? Reprod Domest Anim, 49:183-190.

Knecht D, Środoń S, Duziński K. 2014b. The influence of boar breed and season on semen parameters. S Afr J Anim Sci, 44:1-9.

Knecht D, Duziński K. 2016. The effect of sex, carcass mass, back fat thickness and lean meat content on pork ham and loin characteristics. Arch Anim Breed, 59:51-57.

Kuehn LA, Nonneman DJ, Klindt JM, Wise TH. 2009. Genetic relationships of body composition, serum leptin, and age of puberty in gilt. J Anim Sci, 87:477483.

Marcoux M, Pomar C, Faucitano L, Brodeur C. 2007. The relationship between different pork carcass lean yield definitions and the market carcass value. Meat Sci, 75:94-102.

Matysiak B, Kawęcka M, Jacyno E, KołodziejSkalska A, Pietruszka A. 2010. Relationships between test of gilts before day at first mating on their reproduction performance. Acta Sci Pol Zootech, 9:2938 .

McPherson FJ, Nielsen SG, Chenoweth PJ. 2014. Seminal factors influencing return to estrus in female pigs following artifiacial insemination. Anim Reprod, 11:24-31.

Mijatović M, Petrović M, Radojković D, Pušić M, Radović Č. 2009. Influence of performance test traits of gilts variability of their reproductive performance as primaparous sows. Biotech Anim Husb, 25:825-831. 
Milligan BN, Dewey CE, de Grau AF. 2002. Neonatal-piglet weight variation and its relation to preweaning mortality and weight gain on commercial farms. Prev Vet Med, 56:119-127.

Nowachowicz J, Michalska G, Bucek T, Wasilewski PD. 2009. Meat and fat content of crossbred gilts born and kept in Poland in Bydgoszcz breeding district in years 1995-2004. J Cent Eur Agric, 10:367-374.

Patterson JL, Beltranena E, Foxcroft GR. 2010. The effect of gilt age at first estrus and breeding on third estrus on sow body weight changes and long-term reproductive performance. J Anim Sci, 88:2500-2513.

Quinton VM, Wilton JW, Robinson JA, Mathur PK. 2006. Economic weights for sow productivity traits in nucleus pig populations. Livest Sci, 99:69-77.

Resurreccion AVA. 2004. Sensory aspects of consumer choices for meat and meat products. Meat Sci, 66:11-20.

Roehe R. 1999. Genetic determination of individual birth weight and its association with sow productivity traits using Bayesian analyses. J Anim Sci, 77:330-343.

Roongsitthichai A, Tummaruk P. 2014. Important of backfat thickness to reproductive performance in female pigs. Thai J Vet Med, 44:171-178.

Rozeboom DW, Pettigrew JE, Moser RL, Cornelius SG, el Kandelgy SM. 1996. Influence of gilt age and body composition at first breeding on sow reproductive performance and longevity. J Anim Sci, 74:138-150.

STATISTICA. 2014. Data analysis, software system.
Version 10. Palo Alto, CA: StatSoft Inc.

Szulc K, Knecht D, Jankowska-Mąkosa A, Skrzypczak E, Nowaczewski S. 2013. The influence of fattening and slaughter traits on reproduction in Polish Large White sows. Ital J Anim Sci, 12:16-20.

Tummaruk P, Lundeheim N, Einarsson S, Dalin AM. 2001. Effect of birth litter size, birth parity number, growth rate, backfat thickness and age at first mating of gilts on their reproductive performance as sow. Anim Reprod Sci, 66:225-235.

Vanroose G, de Kruif A, van Soom A. 2000. Embryonic mortality and embryo-pathogen interactions. Anim Reprod Sci, 60/61:131-143.

Wolf J, Žáková E, Groeneveld E. 2008. Within-litter variation of birth weight in hyperprolific Czech Large White sows and its relation to litter size traits, stillborn piglets and losses until weaning. Livest Sci, 115:195205.

Zak LJ, Williams IH, Foxcroft GR, Pluskie JR, Cegielski AC, Clowes EJ, Aherne FX. 1998. Feeding lactating primiparous sows to establish three divergent metabolic states: I. Associated endocrine changes and postweaning reproductive performance. J Anim Sci, 76:1145-1153.

Zhang S, Bidanel JP, Burlot T, Legaut C, Naveau J. 2000. Genetic parameters and genetic trends in the Chinesa $\times$ European Tiameslan composite pig line. I. Genetic parameters. Genet Sel Evol, 32:41-56. 